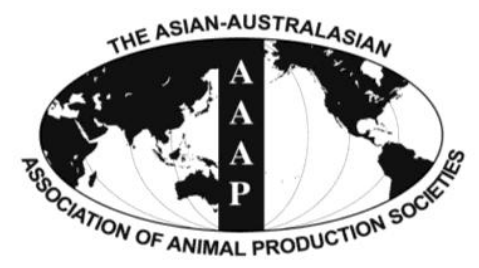

Asian Australas. J. Anim. Sci.

Vol. 26, No. 12 : 1698-1707 December 2013

http://dx.doi.org/10.5713/ajas.2013.13260

www.ajas.info

pISSN 1011-2367 elSSN 1976-5517

\title{
In vitro Evaluation of Different Feeds for Their Potential to Generate Methane and Change Methanogen Diversity
}

\author{
Seon-Ho Kim, Lovelia L. Mamuad, Chang-Dae Jeong, Yeon-Jae Choi, Sung Sill Lee ${ }^{1}$, \\ Jong-Youl $\mathrm{Ko}^{2}$, and Sang-Suk Lee* \\ Ruminant Nutrition and Anaerobe Laboratory, Department of Animal Science and Technology, \\ Sunchon National University, Suncheon, Jeonnam 540-742, Korea
}

\begin{abstract}
Optimization of the dietary formulation is the most effective way to reduce methane. Nineteen feed ingredients (brans, vegetable proteins, and grains) were evaluated for their potential to generate methane and change methanogen diversity using an in vitro ruminal fermentation technique. Feed formulations categorized into high, medium and low production based on methane production of each ingredient were then subjected to in vitro fermentation to determine the real methane production and their effects on digestibility. Methanogen diversity among low, medium and high-methane producing groups was analyzed by PCR-DGGE. The highest methane production was observed in Korean wheat bran, soybean and perilla meals, and wheat and maize of brans, vegetable protein and cereal groups, respectively. On the other hand, corn bran, cotton seed meal and barley led to the lowest production in the same groups. Nine bacteria and 18 methanogen 16s rDNA PCR-DGGE dominant bands were identified with 83\% to 99\% and 92\% to 100\% similarity, respectively. Overall, the results of this study showed that methane emissions from ruminants can be mitigated through proper selection of feed ingredients to be used in the formulation of diets. (Key Words: Feeds Evaluation, Methanogen Diversity, Methane Production, Ruminal Fermentation)
\end{abstract}

\section{INTRODUCTION}

The greenhouse effect of methane is 20 to 50 times that of carbon dioxide (Beauchemin and McGinn, 2005). Owing to the rising concern regarding global warming, researchers are now conducting studies to identify methods of mitigating methane emissions through manipulation of the ruminant diet. Protein, starch and plant cell walls consumed by ruminants are primarily hydrolyzed by microorganisms such as bacteria, protozoa and fungi to produce amino acids and sugars, which are further metabolized by the primary or secondary microorganisms, leading to the production of volatile fatty acids (VFA), hydrogen, carbon dioxide and ammonia (Moore and Dalva, 1997; Zhou et al., 2001; Lee et al., 2003). Accumulation of hydrogen inside the rumen as a

\footnotetext{
* Corresponding Author: Sang Suk Lee. Tel: +82-61-750-3237, Fax: +82-61-750-3237, E-mail: rumen@ scnu.kr

${ }^{1}$ Department of Applied Life Science, Gyeongsang National University, Jinju 660-701, Korea.

${ }^{2}$ Nonghyup Feed, 451, Seongnae 1-Dong, National Livestock Cooperation Federation, Gangdong-Gu, Seoul 134-763, Korea. Submitted May 10, 2013; Accepted Aug. 5, 2013; Revised Aug. 18, 2013
}

major end product of fermentation does not occur since other bacteria, mainly methanogens, utilize the hydrogen to produce methane.

Effects of many factors affecting enteric methane production such as feed intake, digestibility, species, physiological state, concentrates and roughage ratio (Moe and Tyrrell, 1979) are being investigated. McDonald et al. (1995) reported that carbohydrate content in the raw materials of feed contributes $40 \%$ to the total gas production. While structural carbohydrate content in plants impact the generation of methane (Kimihiro and Matsui, 2008), crude proteins are also metabolized, generating $\mathrm{NH}_{4}$, which is subsequently utilized to form methane. The established consortium between methanogens and cellulolytic rumen microbes facilitates the production of methane from the feed crude fiber metabolism (Getachew et al., 1998). This scenario describes how methane production is affected by the nutritional content of the ruminant feed. In the present study, the impact of different feed nutrients and their correlation to each other and level of methane production were determined. Methane emissions and other fermentation parameters from individual feed ingredients in 
each group (brans, vegetable proteins and cereals) were determined using an in vitro ruminal fermentation technique. In addition, changes in the diversity of methanogenic microbes with respect to levels of methane production were investigated.

\section{MATERIALS AND METHODS}

\section{Experimental feeds and experimental design}

Nineteen different feed ingredients with known nutrient compositions were used in this study. The ingredients were divided into three groups, brans (corn gluten feed, palm kernel and wheat from China and Korea), vegetable proteins (cottonseed meal, soybean meal, rapeseed meal, coconut meal, lupine seed, Distillers dried grain makgeolli by-product, corn distillers dried grain with solubles, corn gluten, perilla meal, and whole soybean), and cereals (barley, corn, corn flakes, and wheat). Representative samples of domestically produced and soybean meals from Brazil were the substrates used in this study. These concentrates were individually evaluated for their capability to produce methane using in vitro rumen fermentation. Table 1 shows the nutrient content of each feed ingredient as analyzed by the Association of Official Analytical Chemists (AOAC, 1990).

A feed formulation was then determined based on methane production of each concentrate ingredient in a group. The formulations were categorized as high (corn gluten feed, soybean and perilla meal, corn), medium (corn gluten feed, rapeseed and coconut meal, wheat) and low (corn gluten feed, palm kernel, distillers dried grains and barley). The formula diets were then subjected to in vitro fermentation to determine the methane production, as well as its effects on digestibility and methanogen diversity.

\section{Rumen fluid collection and buffer preparation}

Ruminal fluid was collected from ruminally cannulated Holstein cows (average weight $650 \mathrm{~kg}$ ) fed twice a day with concentrate and rice straw at a 2:8 ratio. One percent dry matter of each diet was included in the in vitro fermentations. The buffer used in the study was composed of (per liter) $0.45 \mathrm{~g} \mathrm{~K}_{2} \mathrm{HPO}_{4}, 0.45 \mathrm{~g} \mathrm{KH}_{2} \mathrm{PO}_{4}, 0.9 \mathrm{~g}$ $\left(\mathrm{NH}_{4}\right)_{2} \mathrm{SO}_{4}, 0.12 \mathrm{~g} \mathrm{CaCl}_{2}{ }_{2} \mathrm{H}_{2} \mathrm{O}, 0.19 \mathrm{~g} \mathrm{MgSO}_{4} \cdot 7 \mathrm{H}_{2} \mathrm{O}, 1.0 \mathrm{~g}$ trypticase peptone, $1.0 \mathrm{~g}$ yeast extract, and $0.6 \mathrm{~g}$ cysteine. $\mathrm{HCl}$ with a final $\mathrm{pH}$ of 6.9 (Asanuma et al., 1999). Rumen fluid and buffer were mixed at a ratio of 1:3 and bubbled with nitrogen $\left(\mathrm{N}_{2}\right)$ gas. Twenty $\mathrm{mL}$ of buffered rumen fluid was anaerobically $\left(\mathrm{O}_{2}\right.$-free $\mathrm{N}_{2}$ gas $)$ dispensed in serum bottles, and then sealed with butyl-rubber stoppers and aluminum caps. Each sample was replicated three times and maintained in a shaking incubator $(80 \mathrm{rpm})$ at $39^{\circ} \mathrm{C}$. During incubation, in vitro fermentation parameters were monitored at $0,2,4,8,12,24,48$, and $72 \mathrm{~h}$. Changes in methanogen diversity in the low, medium and high-methane producing groups of feed ingredients were analyzed using Polymerase

Table 1. Nutrient composition of different feed ingredients (\% DM)

\begin{tabular}{|c|c|c|c|c|c|c|c|}
\hline \multirow{2}{*}{ Item } & & \multicolumn{6}{|c|}{ Nutrient composition } \\
\hline & & Crude protein & Ether extract & $\mathrm{NFE}^{3}$ & Crude fiber & Crude ash & $\mathrm{TDN}^{4}$ \\
\hline \multirow[t]{4}{*}{ Brans } & Corn bran & 18.94 & 2.85 & 53.34 & 10.11 & 6.01 & 75.05 \\
\hline & Wheat bran (Korea) & 15.21 & 3.63 & 54.19 & 9.61 & 4.38 & 62.82 \\
\hline & Wheat bran (USA) & 15.12 & 3.97 & 54.98 & 9.05 & 4.72 & 63.69 \\
\hline & Palm kernel & 15.00 & 7.75 & 49.50 & 15.24 & 4.42 & 77.43 \\
\hline \multirow{11}{*}{$\begin{array}{c}\text { Vegetable } \\
\text { proteins }\end{array}$} & Cotton seed meal & 35.46 & 3.48 & 34.57 & 18.99 & 7.50 & 71.09 \\
\hline & Soybean meal (Korea) & 45.00 & 1.96 & 28.64 & 5.60 & 6.20 & 76.17 \\
\hline & Soybean meal (Brazil) & 45.10 & 0.63 & 33.02 & 3.36 & 6.38 & 76.21 \\
\hline & Rapeseed meal & 38.56 & 1.18 & 34.38 & 8.74 & 7.24 & 64.74 \\
\hline & Coconut meal & 21.68 & 1.57 & 49.31 & 11.57 & 6.64 & 66.05 \\
\hline & Lupine seed & 31.05 & 5.00 & 36.75 & 14.90 & 2.80 & 83.79 \\
\hline & Distillers dried grain ${ }^{1}$ & 27.50 & 4.75 & 36.37 & 11.88 & 8.26 & 75.21 \\
\hline & Corn DDGS ${ }^{2}$ & 25.55 & 12.17 & 38.62 & 7.60 & 4.12 & 82.22 \\
\hline & Corn gluten & 60.00 & 1.50 & 24.90 & 0.80 & 2.80 & 79.02 \\
\hline & Perilla meal & 42.00 & 1.00 & 21.10 & 15.50 & 8.60 & 55.86 \\
\hline & Whole soybean & 36.00 & 18.50 & 28.00 & 5.50 & 5.00 & 96.31 \\
\hline \multirow[t]{4}{*}{ Cereals } & Maize & 6.53 & 3.11 & 72.48 & 2.09 & 1.13 & 78.25 \\
\hline & Barley & 9.54 & 1.70 & 67.59 & 5.50 & 2.67 & 71.92 \\
\hline & Wheat & 11.20 & 1.35 & 73.45 & 2.68 & 1.52 & 78.25 \\
\hline & Corn flakes & 9.79 & 3.31 & 83.62 & 1.75 & 1.52 & 92.97 \\
\hline
\end{tabular}

\footnotetext{
${ }^{1}$ Distillers dried grain - makgeolli byproduct. ${ }^{2}$ Corn distillers dried grain with soluble.
}

${ }^{3}$ Nitrogen-free extract. ${ }^{4}$ TDN-Total digestible nutrients. 
Chain Reaction- Denaturing gradient gel electrophoresis (PCR-DGGE). Samples for PCR-DGGE were taken at 12, 24 , and $48 \mathrm{~h}$.

\section{Analyses of in vitro fermentation parameters}

Total gas production at different stages was measured in each of the serum bottles using a press and sensor machine (Laurel Electronics, Inc., Costa Mesa, CA), while pH was measured with a Pinnacle series M530p meter (Schott instruments, Mainz, Germany) after uncapping each of the bottles. $\mathrm{NH}_{3}-\mathrm{N}$ concentration was measured according to the methods developed by (Chaney and Marbach, 1962).

One $\mathrm{mL}$ of the total gas produced during the in vitro fermentation process was used to determine the methane and carbon dioxide emitted during the incubation period. Gas chromatography (Agilent Technologies HP 5890) was conducted using a TCD detector with a Column Carboxen 1006PLOT capillary column $30 \mathrm{~m} \times 0.53 \mathrm{~mm}$ (Supelco). Methane produced was estimated using the formula described by Ørskov and McDonald (1979). VFA and other metabolites were analyzed by high performance liquid chromatography (HPLC) (Agilent Technologies 1200 series, USA) with a UV detector set at $210 \mathrm{~nm}$ and $220 \mathrm{~nm}$ and a MetaCarb 87H (Varian, Germany) column using $0.0085 \mathrm{~N}$ $\mathrm{H}_{2} \mathrm{SO}_{4}$ solvent applied as a buffer at a rate of $0.6 \mathrm{~mL} / \mathrm{min}$ according to the methods described by Han et al. (2005) and Tabaru et al. (1988).

\section{Denaturing gradient gel electrophoresis}

Fermented samples (preserved) taken at 0,24 , and $48 \mathrm{~h}$ were extracted using Wizard Genomic DNA Purification Kits (Promega, USA). Genomic DNA (gDNA) PCR amplification was performed using the $27 \mathrm{~F}$ and $1492 \mathrm{R}$ primers for bacteria, while Met $86 f$ and Met $915 \mathrm{r}$ were used for methanogens. DGGE was performed using a D-Code Universal Mutation Detection System (Bio-Rad, Hercules, CA, USA). To amplify the V3 region of $16 \mathrm{~S}$ rDNA amplicons, the 341F-GC and 518R primers (Nübel et al., 1996) were used for bacteria, while ARC $344 \mathrm{f}-\mathrm{GC}$ and 519r were used for archaea.

Amplicons of the V3 region of 16S rDNA were used for sequence-specific separation by DGGE according to the specifications of Muyzer and Smalla (1998). The DGGE gel was scanned at $400 \mathrm{dpi}$ and similarity indices were calculated for pairs of DGGE profiles. The number of DGGE bands and similarity indices were calculated from the densitometric curves of the scanned DGGE profiles using the Molecular Analyst 1.12 software (Bio-Rad) and the Pearson product-moment correlation coefficient (Häne et al., 1993; Simpson et al., 1999) by the Central Microbiology Laboratory of SCNU in Korea. Bands of interest were excised from the gel, eluted in $50 \mu \mathrm{L}$ sterile distilled water and incubated overnight at $4{ }^{\circ} \mathrm{C}$. Eluted gels were then amplified using non GC bacteria and archaea primers. The PCR product was purified with a QiaQuick PCR purification kit in accordance with the manufacturer's instructions, after which PCR products were sent to Macrogen, Seoul, Korea for sequencing. The results were compared to those in the GenBank database using the BLAST tool of the National Center for Biotechnology Information (NCBI) and EzTaxon.

\section{Statistical analysis}

All treatments were conducted in triplicate. PearsonProduct Moment Correlation analysis was used to determine significant relationships between and among the different parameters used in the study. A $p<0.05$ was considered to indicate statistical significance. All analyses were carried out using Statistical Analysis Systems (SAS) version 9.1 (2002).

\section{RESULTS AND DISCUSSION}

\section{Feed ingredient evaluation}

Increasing concentrates is one of the methane mitigation strategies. Commercially produced concentrates vary in their nutrient composition and thus may differ in their methane production. The detailed nutrient composition of feed ingredients is shown in Table 1. According to their compositional characteristics, the feeds were grouped as brans, vegetable proteins and cereals. The highest total digestible nutrient (TDN) levels were found in palm kernel, whole soybean and corn flakes for the bran, vegetable protein and cereal groups, respectively.

The correlation analysis of different in vitro fermentation parameters of four feed ingredients categorized as bran is shown in Table 2. The $\mathrm{pH}$ of feed ingredients was negatively correlated with all parameters except for the $\mathrm{A} / \mathrm{P}$ ratio, which was also negatively correlated with all parameters except $\mathrm{pH}$ and $\mathrm{CO}_{2}$. Almost all correlations of fermentation parameters were significant $(\mathrm{p}<0.01, \mathrm{p}<0.05)$ in the bran's group, except for the positive correlation of $\mathrm{A} / \mathrm{P}$ with $\mathrm{pH}$ and $\mathrm{CO}_{2}$, and the negative correlation of $\mathrm{CO}_{2}$ with acetic acid production $(\mathrm{p}>0.05)$. When vegetable protein ingredients were used as fermentation substrates, $\mathrm{pH}$ and $\mathrm{A} / \mathrm{P}$ were positively correlated with each other, while the relationship of these two parameters with other parameters was found to be negative (Table 3). Significant correlations were observed for all parameters $(\mathrm{p}<0.01, \mathrm{p}<0.05)$, except between $\mathrm{pH}$ and butyric acid ( $p>0.05)$. Similarly, the positive relationship of $\mathrm{pH}$ and $\mathrm{A} / \mathrm{P}$ ratio was observed when cereal feed ingredients were used as the substrate, while correlations of other parameters to these two parameters were negative (Table 4). Correlations observed were all significant $(\mathrm{p}<0.01, \mathrm{p}<0.05)$, except for the positive correlation of propionic with butyric 
Table 2. Correlation analysis of in vitro fermentation parameters obtained using brans as substrate

\begin{tabular}{|c|c|c|c|c|c|c|c|c|c|c|}
\hline & $\mathrm{pH}$ & TG & $\mathrm{CO}_{2}$ & $\mathrm{CH}_{4}$ & Acetic & Propionic & Butyric & TVFA & AP & SEM \\
\hline $\mathrm{pH}$ & & $-0.371 * *$ & $-0.499 * *$ & $-0.280 *$ & $-0.561 * *$ & $-0.234^{*}$ & $-0.305^{*}$ & $-0.434 * *$ & 0.037 & 0.623 \\
\hline TG & & & $0.779 * *$ & $0.830 * *$ & $0.718 * *$ & $0.671 * *$ & $0.544 * *$ & $0.821 * *$ & $-0.339 *$ & 3.026 \\
\hline $\mathrm{CO}_{2}$ & & & & $0.716 * *$ & $0.779 * *$ & $0.448 * *$ & $0.654 * *$ & $0.720 * *$ & 0.032 & 4.374 \\
\hline $\mathrm{CH}_{4}$ & & & & & $0.849 * *$ & $0.682 * *$ & $0.678 * *$ & $0.911 * *$ & $-0.268^{*}$ & 2.025 \\
\hline Acetic & & & & & & $0.538 * *$ & $0.598 * *$ & $0.898 * *$ & -0.005 & 7.156 \\
\hline Propionic & & & & & & & $0.658 * *$ & $0.845^{* *}$ & $-0.779 * *$ & 4.781 \\
\hline Butyric & & & & & & & & $0.753 * *$ & $-0.302 *$ & 1.135 \\
\hline TVFA & & & & & & & & & $-0.409 * *$ & 12.032 \\
\hline $\mathrm{AP}$ & & & & & & & & & & 1.277 \\
\hline
\end{tabular}

* Values are significantly different at $\mathrm{p}<0.05$. ** Values are significantly different at $\mathrm{p}<0.01$.

acid and negative relationship of butyric acid with the $\mathrm{A} / \mathrm{P}$ ratio $(\mathrm{p}>0.05)$. Methane production in all three groups was positively correlated for all parameters except $\mathrm{pH}$ and $\mathrm{A} / \mathrm{P}$ ratio.

Methane production from in vitro fermentation of different feed ingredient substrates was estimated and presented as a percentage of the total gas produced (Table 5). The ingredients were then classified as either low, medium or high methane producing substrates based on the method described by Ørskov and McDonald (1979) (Table $6)$. The lowest amounts of methane were produced after 72 $\mathrm{h}$ of incubation when corn bran, cottonseed meal and barley of the bran, vegetable protein and cereal groups, respectively, were used as fermentation substrates while using Korean wheat bran, imported soybean and perilla meals, and maize of the same respective groups resulted in the highest amounts of methane emitted. Methane production of different feed ingredients differs due to nutrient composition, grain type and processing, and digestibility. Qin et al. (2012) reported that wheat had relatively higher effective degradability of dry matter (EDDM), which was more rapidly fermented by ruminal microbes. Thus, having a higher methane production of wheat in this study may be attributed to EDDM. Moreover, low methane production of other feed ingredients might also be attributed to low EDDM and thus slow fermentation of ruminal microbes. Low EDDM might be due to the thickness of the protein matrix which coats starch granules,

Table 3. Correlation analysis of in vitro fermentation parameters using vegetable proteins as substrate

\begin{tabular}{|c|c|c|c|c|c|c|c|c|c|c|}
\hline & $\mathrm{pH}$ & TG & $\mathrm{CO}_{2}$ & $\mathrm{CH}_{4}$ & Acetic & Propionic & Butyric & TVFA & $\mathrm{A} / \mathrm{P}$ & SEM \\
\hline$\overline{\mathrm{pH}}$ & & $-0.422 * *$ & $-0.379 * *$ & $-0.346 * *$ & $-0.540 * *$ & $-0.580 * *$ & -0.047 & $-0.605 * *$ & $0.630 * *$ & 0.493 \\
\hline TG & & & $0.752 * *$ & $0.775 * *$ & $0.700 * *$ & $0.722 * *$ & $0.522 * *$ & $0.817 * *$ & $-0.608 * *$ & 5.732 \\
\hline $\mathrm{CO}_{2}$ & & & & $0.704 * *$ & $0.773 * *$ & $0.821 * *$ & $0.443 * *$ & $0.872 * *$ & $-0.711 * *$ & 3.456 \\
\hline $\mathrm{CH}_{4}$ & & & & & $0.704 * *$ & $0.509 * *$ & $0.462 * *$ & $0.693 * *$ & $-0.372 * *$ & 1.003 \\
\hline Acetic & & & & & & $0.735 * *$ & $0.322 * *$ & $0.915 * *$ & $-0.483 * *$ & 6.597 \\
\hline Propionic & & & & & & & $0.434 * *$ & $0.919 * *$ & $-0.877 * *$ & 6.146 \\
\hline Butyric & & & & & & & & $0.559 * *$ & $-0.410 * *$ & 2.253 \\
\hline TVFA & & & & & & & & & $-0.738 * *$ & 13.755 \\
\hline $\mathrm{AP}$ & & & & & & & & & & 1.200 \\
\hline
\end{tabular}

* Values are significantly different at $\mathrm{p}<0.05$. ** Values are significantly different at $\mathrm{p}<0.01$.

Table 4. Correlation analysis of parameters obtained using cereals as substrate

\begin{tabular}{|c|c|c|c|c|c|c|c|c|c|c|}
\hline & $\mathrm{pH}$ & TG & $\mathrm{CO}_{2}$ & $\mathrm{CH}_{4}$ & Acetic & Propionic & Butyric & TVFA & $\mathrm{A} / \mathrm{P}$ & SEM \\
\hline $\mathrm{pH}$ & & $-0.673^{* *}$ & $-0.704 * *$ & $-0.544 * *$ & $-0.697 * *$ & $-0.577 * *$ & $-0.373^{*}$ & $-0.630 * *$ & $0.610 * *$ & 0.773 \\
\hline TG & & & $0.966 * *$ & $0.915 * *$ & $0.903 * *$ & $0.874 * *$ & $0.519 * *$ & $0.932 * *$ & $-0.911 * *$ & 6.674 \\
\hline $\mathrm{CO}_{2}$ & & & & $0.880 * *$ & $0.933 * *$ & $0.906^{* *}$ & $0.420^{*}$ & $0.940 * *$ & $-0.900 * *$ & 3.752 \\
\hline $\mathrm{CH}_{4}$ & & & & & $0.754 * *$ & $0.700 * *$ & $0.714 * *$ & $0.831 * *$ & $-0.850 * *$ & 3.144 \\
\hline Acetic & & & & & & $0.957 * *$ & $0.324 *$ & $0.977 * *$ & $-0.859 * *$ & 6.977 \\
\hline Propionic & & & & & & & 0.153 & $0.955 * *$ & $-0.904 * *$ & 5.993 \\
\hline Butyric & & & & & & & & $0.462 *$ & -0.267 & 3.551 \\
\hline TVFA & & & & & & & & & $-0.910 * *$ & 16.090 \\
\hline $\mathrm{AP}$ & & & & & & & & & & 1.045 \\
\hline
\end{tabular}

* Values are significantly different at $\mathrm{p}<0.05 . * *$ Values are significantly different at $\mathrm{p}<0.01$. 
Table 5. Feed methane concentrations after different incubation periods

\begin{tabular}{|c|c|c|c|c|c|c|c|c|}
\hline \multirow{2}{*}{ Item } & & \multicolumn{7}{|c|}{ Incubation times $(\mathrm{h})$} \\
\hline & & 2 & 4 & 8 & 12 & 24 & 48 & 72 \\
\hline \multirow[t]{5}{*}{ Brans } & Corn bran & $0.43^{\mathrm{c}}$ & $0.30^{\mathrm{c}}$ & $0.39^{\mathrm{c}}$ & $0.37^{\mathrm{c}}$ & $0.45^{\mathrm{c}}$ & $0.53^{\mathrm{b}}$ & $0.69^{c}$ \\
\hline & Wheat bran (Korea) & $3.28^{\mathrm{a}}$ & $5.23^{\mathrm{a}}$ & $7.26^{\mathrm{a}}$ & $7.89^{\mathrm{a}}$ & $8.96^{\mathrm{a}}$ & $10.50^{\mathrm{a}}$ & $10.99^{\mathrm{a}}$ \\
\hline & Wheat bran (USA) & $1.43^{\mathrm{b}}$ & $2.22^{\mathrm{b}}$ & $3.52^{\mathrm{b}}$ & $3.79^{\mathrm{b}}$ & $4.16^{\mathrm{b}}$ & $4.71^{\mathrm{ab}}$ & $5.06^{\mathrm{b}}$ \\
\hline & Palm kernel & $1.60^{\mathrm{b}}$ & $3.01^{\mathrm{b}}$ & $3.96^{\mathrm{b}}$ & $4.03^{\mathrm{b}}$ & $4.10^{\mathrm{b}}$ & $5.53^{\mathrm{ab}}$ & $5.05^{\mathrm{b}}$ \\
\hline & SEM & 0.126 & 0.225 & 0.340 & 0.369 & 0.266 & 1.211 & 0.531 \\
\hline \multirow{12}{*}{$\begin{array}{l}\text { Vegetable } \\
\text { proteins }\end{array}$} & Cotton seed meal & $1.45^{\mathrm{d}}$ & $2.76^{\mathrm{f}}$ & $3.97^{\mathrm{e}}$ & $3.33^{\mathrm{f}}$ & $3.43^{\mathrm{e}}$ & $3.86^{\mathrm{f}}$ & $4.08^{\mathrm{e}}$ \\
\hline & Soybean meal (Korea) & $2.88^{\mathrm{b}}$ & $5.04^{\mathrm{cd}}$ & $7.15^{\mathrm{c}}$ & $7.24^{\mathrm{de}}$ & $7.58^{\mathrm{bc}}$ & $11.69^{c}$ & $10.55^{\mathrm{b}}$ \\
\hline & Soybean meal (Brazil) & $2.87^{\mathrm{b}}$ & $6.56^{\mathrm{ab}}$ & $10.18^{\mathrm{a}}$ & $10.76^{\mathrm{b}}$ & $13.94^{\mathrm{a}}$ & $18.32^{\mathrm{a}}$ & $17.88^{\mathrm{a}}$ \\
\hline & Rapeseed meal & $2.05^{\mathrm{c}}$ & $3.73^{\mathrm{e}}$ & $5.21^{\mathrm{d}}$ & $6.61^{\mathrm{e}}$ & $7.38^{\mathrm{bc}}$ & $7.30^{\mathrm{de}}$ & $7.31^{\text {bcde }}$ \\
\hline & Coconut meal & $2.78^{\mathrm{b}}$ & $4.97^{\mathrm{cd}}$ & $8.80^{\mathrm{b}}$ & $9.61 b^{c}$ & $8.89^{\mathrm{b}}$ & $8.90^{\mathrm{cd}}$ & $9.75^{\mathrm{bc}}$ \\
\hline & Lupine seed & $3.20^{\mathrm{ab}}$ & $6.95^{\mathrm{a}}$ & $10.88^{\mathrm{a}}$ & $12.62^{\mathrm{a}}$ & $14.53^{\mathrm{a}}$ & $14.81^{\mathrm{b}}$ & $15.15^{\mathrm{a}}$ \\
\hline & Distillers dried grain ${ }^{1}$ & $1.81^{\mathrm{cd}}$ & $2.69^{f}$ & $3.86^{\mathrm{e}}$ & $4.82^{\mathrm{f}}$ & $5.16^{\mathrm{de}}$ & $4.84^{\mathrm{ef}}$ & $4.64^{\mathrm{de}}$ \\
\hline & Corn DDGS ${ }^{2}$ & $2.82^{\mathrm{b}}$ & $4.73^{\mathrm{d}}$ & $8.32^{\mathrm{b}}$ & $6.98^{\mathrm{de}}$ & $7.13^{\mathrm{bcd}}$ & $8.98^{\mathrm{cd}}$ & $8.69^{\mathrm{bcd}}$ \\
\hline & Corn gluten & $1.56^{\mathrm{d}}$ & $2.91^{\mathrm{ef}}$ & $4.14^{\mathrm{e}}$ & $4.31^{\mathrm{f}}$ & $5.49^{\text {cde }}$ & $5.57^{\mathrm{ef}}$ & $5.51^{\text {cde }}$ \\
\hline & Perilla meal & $1.63^{\mathrm{cd}}$ & $3.36^{\mathrm{ef}}$ & $6.57^{\mathrm{c}}$ & $8.17^{\text {cde }}$ & $14.96^{\mathrm{a}}$ & $15.82^{\mathrm{ab}}$ & $17.89^{\mathrm{a}}$ \\
\hline & Whole soybean & $3.39^{\mathrm{a}}$ & $5.72^{\mathrm{bc}}$ & $8.48^{\mathrm{b}}$ & $8.52^{\mathrm{cd}}$ & $8.68^{\mathrm{b}}$ & $10.23^{\mathrm{cd}}$ & $9.23 b^{c}$ \\
\hline & SEM & 0.133 & 0.261 & 0.313 & 0.461 & 0.529 & 0.769 & 0.963 \\
\hline \multirow[t]{5}{*}{ Cereals } & Maize & 3.57 & 7.62 & $12.27^{\mathrm{a}}$ & $14.93^{\mathrm{a}}$ & $21.33^{\mathrm{a}}$ & $23.00^{\mathrm{a}}$ & $22.33^{\mathrm{a}}$ \\
\hline & Barley & 3.57 & 5.33 & $7.27^{\mathrm{c}}$ & $8.13^{\mathrm{c}}$ & $8.17^{\mathrm{c}}$ & $10.87^{\mathrm{c}}$ & $11.80^{\mathrm{b}}$ \\
\hline & Wheat & 3.63 & 6.47 & $8.53^{\mathrm{b}}$ & $10.33^{\mathrm{b}}$ & $11.60^{\mathrm{b}}$ & $22.13^{\mathrm{ab}}$ & $24.20^{\mathrm{a}}$ \\
\hline & Corn flakes & 4.50 & 5.87 & $8.20^{\mathrm{bc}}$ & $10.67^{\mathrm{b}}$ & $14.93^{\mathrm{b}}$ & $19.27^{\mathrm{b}}$ & $20.80^{\mathrm{a}}$ \\
\hline & SEM & 0.268 & 0.187 & 0.299 & 0.408 & 0.927 & 0.796 & 1.104 \\
\hline
\end{tabular}

${ }^{1}$ Distillers dried grain - makgeolli byproduct. ${ }^{2}$ Corn distillers dried grain with solubles.

* Values are means of triplicates \pm standard error; means with different superscripts $\left({ }^{\mathrm{a}, \mathrm{b}, \mathrm{c}, \mathrm{d}, \mathrm{e}}\right)$ among treatments are significantly different (p<0.05).

and this matrix is relatively difficult to be hydrolyzed by water and enzyme (McAllister et al., 1990; 1996).

Degradation of feed ingredients also depends on the distribution of starch granules within the kernel (Swan et al., 2006). Qin et al. (2012) added that starch granules of wheat endosperms seem to be floury and have a relatively small particle size. Consequently, the smaller starch granules have a larger surface area available for microbial and enzymatic starch hydrolysis which results to rapid degradation. Bonhomme (1990) reported that increased methane emission can be observed as a result of the optimum symbiotic relationship between bacteria and protozoans and efficient exchange of hydrogen between these microorganisms. Furthermore, methane production is affected by the type of carbohydrate fed to the animals (Moe and Tyrrell, 1979).

Among the groups investigated herein, cereals had the highest methane production. This might be attributed to the high contents of easily fermentable starches, sugars, or hemicelluloses as substrate to rumen microbes for gas production. Methane production of cereals group in this study was similar to that of grains reported by Lee et al.

Table 6. Groups of mixed feed ingredients according to the level of methane production and their corresponding nutrient composition

\begin{tabular}{lllr}
\hline & \multicolumn{1}{c}{ High } & Medium & Low \\
\hline Feed ingredients & & & Corn bran, Palm kernel \\
Bran & Corn bran & Corn bran & Rapeseed meal, \\
Vegetable proteins & Perilla meal, & Coconut meal & Distillers dried grain \\
& Soybean meal (Brazil) & Wheat & Barley \\
Cereals & Corn & & 19.84 \\
Chemical composition unit (\%) & & 23.54 & 2.60 \\
Crude protein & 28.53 & 2.83 & 57.65 \\
Ether extract & 7.99 & 52.54 & 10.54 \\
NFE & 47.44 & 9.36 & 6.34 \\
Crude fiber & 10.27 & 6.01 & 73.99 \\
Crude ash & 5.60 & 55.27 & \\
TDN & 58.82 & & \\
\hline
\end{tabular}


Table 7. Correlation analyses of fermentation parameters using high, medium and low methane producing feed ingredient as substrate

\begin{tabular}{|c|c|c|c|c|c|c|c|c|c|c|}
\hline & $\mathrm{pH}$ & TG & $\mathrm{CO}_{2}$ & $\mathrm{CH}_{4}$ & Acetic & Propionic & Butyric & VFA & $\mathrm{A} / \mathrm{P}$ & SEM \\
\hline $\mathrm{pH}$ & & $-0.630 * *$ & $-0.623 * *$ & $-0.480 * *$ & $-0.626 * *$ & $-0.646 * *$ & -0.171 & $-0.643 * *$ & $0.735 * *$ & 0.602 \\
\hline TG & & & $0.964 * *$ & $0.914 * *$ & $0.959^{*}$ & $0.829 * *$ & $0.851 * *$ & $0.939 * *$ & $-0.708 * *$ & 7.030 \\
\hline $\mathrm{CO}_{2}$ & & & & $0.934 * *$ & $0.945 * *$ & $0.854 * *$ & $0.815 * *$ & $0.936 * *$ & $-0.729 * *$ & 3.487 \\
\hline $\mathrm{CH}_{4}$ & & & & & $0.891 * *$ & $0.661 * *$ & $0.784 * *$ & $0.827 * *$ & $-0.534 * *$ & 2.735 \\
\hline Acetic & & & & & & $0.850 * *$ & $0.848 * *$ & $0.958 * *$ & $-0.589 * *$ & 6.055 \\
\hline Propionic & & & & & & & $0.742 * *$ & $0.950 * *$ & $-0.832 * *$ & 6.766 \\
\hline Butyric & & & & & & & & $0.891 * *$ & $-0.614 * *$ & 3.549 \\
\hline VFA & & & & & & & & & $-0.739 * *$ & 15.908 \\
\hline AP & & & & & & & & & & 0.868 \\
\hline
\end{tabular}

* Values are significantly different at $\mathrm{p}<0.05$. ** Values are significantly different at $\mathrm{p}<0.01$.

(2003). Both of these substrates contain high amounts of nitrogen free extract (NFE), which is readily fermented by microbes in the rumen and provides a large amount of substrates to microbes for methane production. Van Nevel and Demeyer (1977) stated that when soluble carbohydrates and starch-rich diets are fed to ruminants, the production of propionate increases and the methane production and the acetate:propionate ratio decreases. Lee et al. (2003) stated that crude fiber is an important component of methane production and that methane production decreased as the content of crude fiber increased. Cereals with the lowest crude fiber had the highest methane production in this study and the observation agrees with these reports.

In vitro fermentation using feed ingredients capable of different levels of methane production as substrate and PCR-DGGE profiling of bacteria and methanogens

Based on the groups of feed ingredients established, mixtures of substrate containing members of the three groups of feed ingredients producing high $(\mathrm{H})$, medium $(\mathrm{M})$ and low (L) levels of methane were prepared and subjected to another in vitro fermentation experiment followed by correlation analysis of the fermentation parameters. The groups of mixed feed ingredients according to the level of methane production and their corresponding nutrient composition is given in Table 6. The low methane production group had the highest NFE but the lowest methane production (Table 5), followed by the medium and high methane production groups. A study of the effects of diet composition and intake on methane production conducted by Shibata (1992) showed that providing ruminants with feed containing carbohydrates and high protein levels had a negative effect on methane emission, while providing a diet rich in fiber resulted in an elevated volume of methane being produced. As shown in Table 7, $\mathrm{pH}$ and $\mathrm{A} / \mathrm{P}$ ratio were positively correlated with each other, while the correlations of these parameters with other parameters were found to be negative. Moreover, almost all correlations were significant $(\mathrm{p}<0.01, \mathrm{p}<0.05)$, except that of $\mathrm{pH}$ with butyric acid. On the other hand, $\mathrm{CH}_{4}$ production was positively correlated with almost all other fermentation parameters $(\mathrm{p}<0.01)$ except for $\mathrm{pH}$ and $\mathrm{A} / \mathrm{P}$ ratio. NFE, TDN and ruminal fermentation have a directly proportional relationship. Thus, increased ruminal fermentation means reduced $\mathrm{pH}$. The low methane group has high NFE and TDN and consequently reduced $\mathrm{pH}$ which inhibits methanogen's activity. According to Van Kessel and Russell (1996), highly digestible carbohydrate undergoes rapid decomposition inside the rumen and causes a reduction in ruminal $\mathrm{pH}$, which inhibits the activity of methane producing microorganisms and protozoa.

Trend analysis of methane production with respect to total volatile fatty acid production showed that the high methane producing group feed formulation (corn bran, rapeseed meal, coconut meal, wheat) had the highest correlation coefficient of 0.857 , followed by the medium methane producing group (corn bran, perilla meal, imported soybean meal, maize) and low methane producing group (corn bran, palm kernel expeller, distillers dried grain, barley) mixtures, which had correlation coefficients of 0.823 and 0.720 , respectively (Figure 1). Moreover, low methane producing group had the lowest methane production but higher VFA production than the medium methane producing group. On the other hand, the high methane producing group produced high methane as well as VFA production.

Feed intake and nutrient content are factors affecting methane production from carbohydrate degradation by rumen bacteria (Moe and Tyrrell, 1979). Numerous microorganisms in the rumen use carbohydrates as an energy source, and $40 \%$ of the total gas produced in the fermentation process is carbon dioxide (McDonald et al., 1995). Substrates such as acetate, methanol, and methylamine are utilized by most bacteria to generate methane from carbon dioxide and hydrogen (Miller et al., 1986). PCR-DGGE was performed using the samples obtained from in vitro ruminal fermentation at 0,24 , and 48 $\mathrm{h}$ of incubation to identify possible changes in the population of bacteria and methanogens associated with variations in the composition of the substrate used. A total 


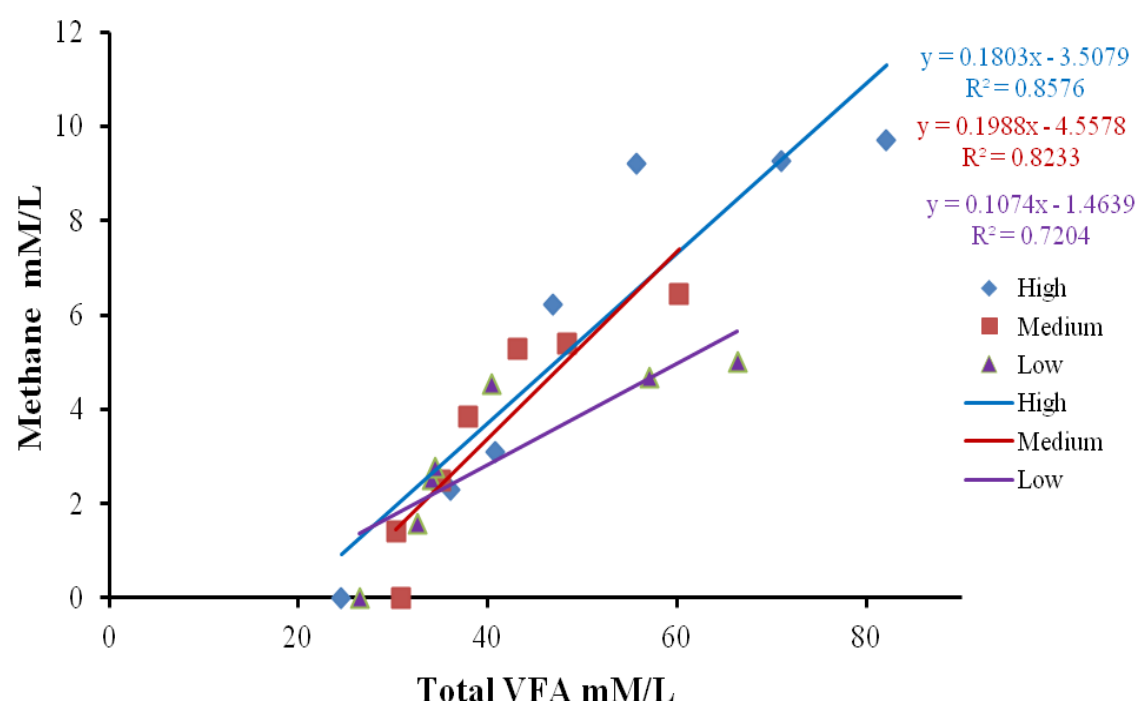

Figure 1. Methane and total VFA concentration relationship using high, medium and low methane-producing feed formulation as substrates. Line indicates the linear regression's trend line of different substrates.

of 9 bacterial $16 \mathrm{~S}$ rDNA bands were successfully cloned and sequenced (Figure 2). All treatment groups (L, M, and $\mathrm{H})$ had similar microbial diversity at $0 \mathrm{~h}$. However, as the incubation time increased, variations in percent similarity were observed, such that microbial diversity at 24 and $48 \mathrm{~h}$ was more similar in the $\mathrm{H}$ and $\mathrm{L}$ groups than the $\mathrm{M}$ group. All groups produced four similar bands $(6,10,12$, and 16) at $0 \mathrm{~h}$ and 2 similar bands (9 and 13) at 24 and $48 \mathrm{~h}$ incubation. Band 3 was only observed in groups $\mathrm{H}$ and $\mathrm{L}$ at 24 and $48 \mathrm{~h}$, while band 14 was only produced in groups $\mathrm{M}$ and $\mathrm{L}$, and band 11 was only present in group $\mathrm{H}$ at the same incubation time. The nine sequenced bands showed $83 \%$ to $99 \%$ similarity to the genomes of bacterial strains in the GenBank database (Table 8), with three bands
(Lactobacillus amylovorusisolate LA80 [EF439704], L. ultunensis DSM 16047 [ACGU01000081] and Streptococcus lutetiensis CIP106849 [DQ232532]) showing $97 \%$ to $99 \%$ similarity and the remaining six showing $83 \%$ to $92 \%$.

A total of 21 distinctive bands were detected from the PCR-DGGE profiles of groups L, M and $\mathrm{H}$ after 0, 24, and $48 \mathrm{~h}$ of incubation (Figure 3). Profiles from each group exhibited multiple predominant bands that were largely common to all groups at different incubation times (bands 3 , $5,9,10,11,13,16,17$, and 21). Low methane producing feed ingredients had the lowest similarity of methanogens when compared to other samples at 24 and $48 \mathrm{~h}$ of incubation. Eighteen were successfully cloned and

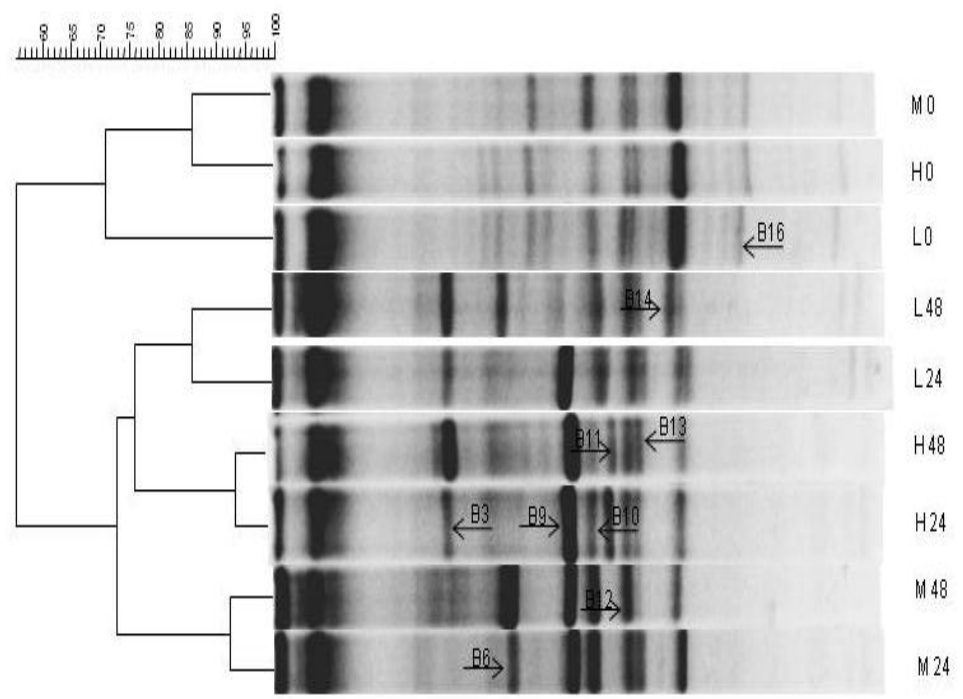

Figure 2. Negative image and similarity index of bacterial 16S rRNA DGGE amplified using total genomic DNA extracted from in vitro fermenta of high, medium and low methane producing feed ingredients as substrate. 
Table 8. Identified bands from bacterial 16S rRNA DGGE using high, medium and low methane producing feed ingredients as substrate

\begin{tabular}{llc}
\hline PCR-DGGE bands* & \multicolumn{1}{c}{ Most closely related taxon (GenBank accession no.) } & Similarity (\%) \\
\hline B3 & Lactobacillus amylovorusisolate LA80 (EF439704) & 97 \\
B6 & Lactobacillus ultunensis DSM 16047 (ACGU01000081) & 99 \\
B9 & Streptococcus lutetiensis CIP106849 (DQ232532) & 99 \\
B10 & Lactobacillus delbrueckii subsp. indicus NCC725 (AY421720) & 89 \\
B11 & Sporanaerobacteracetigenes DSM13106 (GQ461827) & 85 \\
B12 & Lactobacillus ultunensis DSM 16047 (ACGU01000081) & 83 \\
B13 & Prevotella ruminicola Tc2-24 (AJ009933) & 92 \\
B14 & Bacterium enrichment culture clone ALO1 GLFRUDD03GF2UG (JF686930) & 92 \\
B16 & Ruminococcus sp. strain16442 (AJ318889) & 88 \\
\hline
\end{tabular}

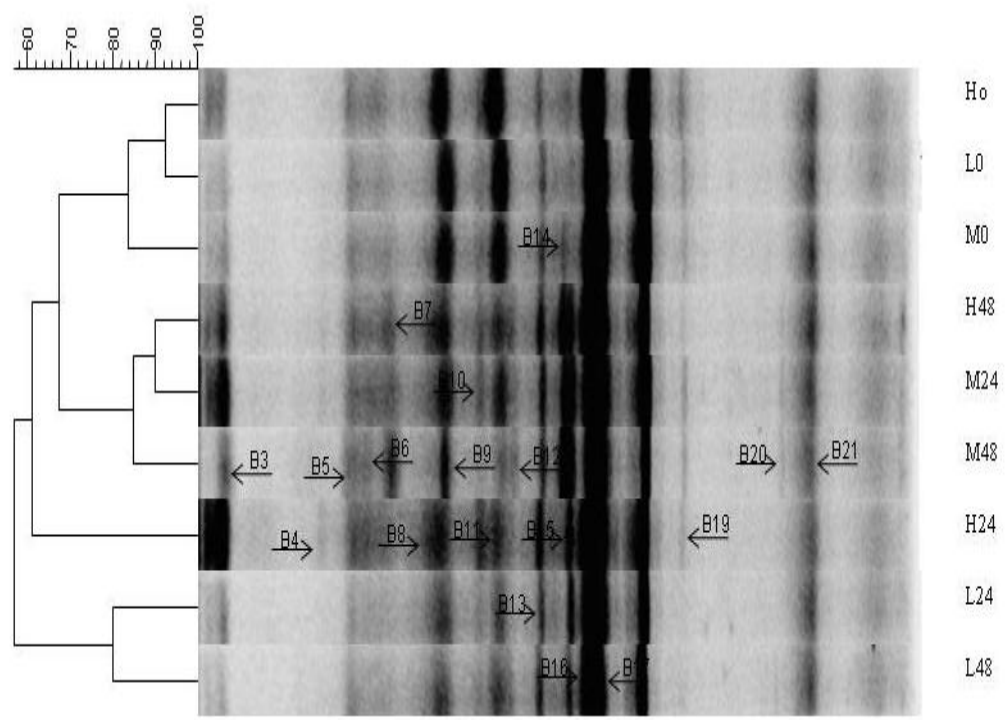

Figure 3. Negative image and similarity index of archaeal 16S rRNA DGGE amplified using total genomic DNA extracted from in vitro fermenta of high, medium and low methane producing feed ingredients as substrate.

Table 9. Identified bands from Archaeal 16S rRNA DGGE using high, medium and low methane producing feed ingredients as substrate

\begin{tabular}{llc}
\hline PCR-DGGE bands* & \multicolumn{1}{c}{ Most related taxon (GenBank accession no.) } & Similarity (\%) \\
\hline B3 & Methanobrevibacter thaueri CW (U55236) & 93 \\
B4 & Methanobrevibacter thaueri CW (U55236) & 96 \\
B5 & Methanobrevibacter smithii ATCC35061 (CP000678) & 97 \\
B6 & Methanobrevibacter smithii ATCC35061 (CP000678) & 99 \\
B7 & Uncultured Methanobrevibacter sp. (FJ468284) & 100 \\
B8 & Methanobrevibacter millerae ZA-10 (AY196673) & 96 \\
B9 & Methanobrevibacter millerae ZA-10 (AY196673) & 98 \\
B10 & Methanobrevibacter millerae ZA-10 (AY196673) & 93 \\
B11 & Methanobrevibacter millerae DSM 16643 (NR042785) & 99 \\
B12 & Methanobrevibacter millerae ZA-10 (AY196673) & 99 \\
B13 & Methanobrevibacter thaueri CW (U55236) & 95 \\
B14 & Methanobrevibacter thaueri CW (U55236) & 97 \\
B15 & Methanobrevibacter thaueri CW (U55236) & 94 \\
B16 & Methanobrevibacter thaueri CW (U55236) & 95 \\
B17 & Methanobrevibacter smithii ATCC35061 (CP000678) & 98 \\
B19 & Methanobrevibacter millerae ZA-10 (AY196673) & 95 \\
B20 & Methanobrevibacter thaueri CW (U55236) & 97 \\
B21 & Methanobrevibacter thaueri CW (U55236) & 94
\end{tabular}


sequenced and found to have $92 \%$ to $100 \%$ similarity to sequences available in the GenBank database (Table 9), representing Methanobrevibacter thaueri CW (U55236) (8 bands), M. millerae ZA-10 (AY196673) (6 bands), and $M$. smithii ATCC35061 (CP000678) (3 bands). According to Zhou et al., most of the sequences obtained from the DGGE bands observed from previous PCR-DGGE profiling analyses of the rumen ecosystem belonged to the genera Methanobrevibacter or Methanosphaera.

\section{CONCLUSION}

Methane production potential of different feed ingredients differs due to nutrient composition, grain type and processing, and digestibility. Methane emissions from ruminants can be mitigated through proper selection of feed ingredients to be used in the formulation of diets. Among feed formulations, low methane producing feed formulation is recommended due to its low methane but high NFE, TDN, and VFA production.

\section{ACKNOWLEDGEMENT}

This research was supported by Bio-industry Technology Development Program, Ministry of Agriculture, Food and Rural Affairs, and Cooperative Research Program for Agriculture Science \& Technology Development, Rural Development Administration and with support of "Cooperative Research Program for Agriculture Science and Technology Development (Project No. PJ0091562013)” ,Rural Development Administration, Republic of Korea.

\section{REFERENCES}

Association of Official Analytical Chemists (AOAC). 1990. Official methods of analysis association of official analytical chemists. 16th ed. AOAC International, Washington, DC.

Asanuma, N., M. Iwamoto, and T. Hino. 1999. Effect of the addition of fumarate on methane production by ruminal microorganisms in vitro. J. Dairy Sci. 82:780-787.

Bano, N., S. Ruffin, B. Ransom, and J. T. Hollibaugh. 2004. Phylogenetic composition of arctic ocean archaeal assemblages and comparison with antarctic assemblages. Appl. Environ. Microbiol. 70:781-789.

Beauchemin, A. K. and S. M. McGinn. 2005. Methane emissions from feedlot cattle fed barley or corn diets. J. Anim. Sci. 83:653-661.

Bonhomme, A. 1990. Rumen ciliates: their metabolism and relationships with bacteria and their hosts. Anim. Feed Sci. Technol. 30:203-266.

Chaney, A. L. and E. P. Marbach. 1962. Modified reagents for determination of urea and ammonia. Clin. Chem. 8:130-132.

Getachew, G., M. Blummel, H. P. S. Makkar, and K. Becker. 1998. In vitro gas measuring techniques for assessment of nutritional quality of feeds: a review. Anim. Feed Sci. Technol. 72:261281.

Häne, B. G., K. Jäger, and H. G. Drexler. 1993. The pearson product-moment correlation coefficient is better suited for identification of DNA fingerprint profiles than band matching algorithms. Electrophoresis 14:967-972.

Han, S.-K., S.-H. Kim, and H.-S. Shin. 2005. UASB treatment of wastewater with VFA and alcohol generated during hydrogen fermentation of food waste. Proc. Biochem. 40:2897-2905.

Kimihiro, H. and H. Matsui. 2008. Diversity of fumarate reducing bacteria in the bovine rumen revealed by culture dependent and independent approaches. Anaerobe 14:87-93.

Lane, D. J. 1991. 16S/23S rRNA sequencing. Nucleic Acid Techniques in Bacterial Systematics.

Lee, H. J., S. C. Lee, J. D. Kim, Y. G. Oh, B. K. Kim, C. W. Kim, and K. J. Kim. 2003. Methane production potential of feed ingredients as measured by in vitro gas test. Asian-Aust. J. Anim. Sci. 16:1143-1150.

McAllister, T. A., E. K. Okine, G. W. Mathison, and K. J. Cheng. 1996. Dietary, environmental and microbiological aspects of methane production in ruminants. Canadian J. Anim. Sci. 76:231-243.

McAllister, T. A., L. M. Rode, D. J. Major, K. J. Cheng, and J. G. Buchanan-Smith. 1990. Effect of ruminal microbial colonization on cereal grain digestion. Canadian J. Anim. Sci. 70:571-579.

McDonald, P., R. A. Edwards, and J. F. D. Greenhalgh. 1995. Animal Nutrition 5th. Longman, London, UK.

Miller, T. L., M. J. Wolin, H. X. Zhao, and M. P. Bryant. 1986. Characteristics of methanogens isolated from bovine rumen. Appl. Environ. Microbiol. 51:201-202.

Moe, W. P. and H. F. Tyrrell. 1979. Methane production in dairy cows. J. Dairy Sci. 62:1583-1586.

Moore, T. R. and M. Dalva. 1997. Methane and carbon dioxide exchange potentials of peat soils in aerobic and anaerobic laboratory incubations. Soil Biol. Biochem. 29:1157-1164.

Muyzer, G., E. C. de Waal, and A. G. Uitterlinden. 1993. Profiling of complex microbial populations by denaturing gradient gel electrophoresis analysis of polymerase chain reactionamplified genes coding for $16 \mathrm{~S}$ rRNA. Appl. Environ. Microbiol. 59:695-700.

Muyzer, G. and K. Smalla. 1998. Application of denaturing gradient gel electrophoresis (DGGE) and temperature gradient gel electrophoresis (TGGE) in microbial ecology. Antonie van Leeuwenhoek 73:127-141.

Nübel, U., B. Engelen, A. Felske, J. Snaidr, A. Wieshuber, R. I. Amann, W. Ludwig, and H. Backhaus. 1996. Sequence heterogeneities of genes encoding 16S rRNAs in Paenibacillus polymyxa detected by temperature gradient gel electrophoresis. J. Bacteriol. 178:5636-5643.

Orskov, E. R. and I. McDonald. 1979. The estimation of protein degradability in the rumen from incubation measurements weighted according to rate of passage. J. Agric. Sci. 92:499503

Qin, W. Z., C. Y. Li, J. K. Kim, J. G. Ju, and M. K. Song. 2012. Effects of defaunation on fermentation characteristics and methane production by rumen microbes in vitro when incubated with starchy feed sources. Asian-Aust. J. Anim. Sci. 25:1381-1388. 
SAS. 2002. SAS/STAT. Statistical analysis systems for Windows. Release 9.1. SAS Institute Inc., Cary, N.C., USA.

Shibata, M. 1992. Methane production in heifers, sheep and goats consuming diets of various hay-concentrate ratios. Anim. Sci. Technol. 63:1221-1227.

Simpson, J. M., V. J. McCracken, B. A. White, H. R. Gaskins, and R. I. Mackie. 1999. Application of denaturant gradient gel electrophoresis for the analysis of the porcine gastrointestinal microbiota. J. Microbiol. Methods 36:167-179.

Swan, C. G., J. G. P. Bowman, J. M. Martin, and M. J. Giroux. 2006. Increased puroindoline levels slow ruminal digestion of wheat (Triticum aestivum L.) starch by cattle. J. Anim. Sci. 84:641-650.

Tabaru, H., E. Kadota, H. Yamada, N. Sasaki, and A. Takeuchi. 1988. Determination of volatile fatty acids and lactic acid in bovine plasma and ruminal fluid by high performance liquid chromatography. Nihon Juigaku Zasshi 50:1124-1126.
Van Kessel, J. A. S. and J. B. Russell. 1996. The effect of pH on ruminal methanogenesis. FEMS Microbiol. Ecol. 20:205-210.

Van Nevel, C. J. and D. I. Demeyer. 1977. Effect of monensin on rumen metabolism in vitro. Appl. Environ. Microbiol. 34:251257.

Watanabe, T., S. Asakawa, A. Nakamura, K. Nagaoka, and M. Kimura. 2004. DGGE method for analyzing 16S rDNA of methanogenic archaeal community in paddy field soil. FEMS Microbiol. Lett. 232:153-163.

Wright, A.-D. G. and C. Pimm. 2003. Improved strategy for presumptive identification of methanogens using $16 \mathrm{~S}$ riboprinting. J. Microbiol. Methods 55:337-349.

Zhou, M., Y. H. Chung, K. A. Beauchemin, L. Holtshausen, M. Oba, T. A. McAllister, and L. L. Guan. 2001. Relationship between rumen methanogens and methane production in dairy cows fed diets supplemented with a feed enzyme additive. J. Appl. Microbiol. 111:1148-1158. 